\title{
Olfactory Marker Protein mRNA Is Found in Axons of Olfactory Receptor Neurons
}

\author{
Cathy H. Wensley, ${ }^{4}$ Donna M. Stone, ${ }^{2}$ Harriet Baker, ${ }^{2}$ John S. Kauer, ${ }_{3}^{3,4}$ Frank L. Margolis, ${ }^{5}$ and Dona M. \\ Chikaraishi ${ }^{1,4}$ \\ ${ }^{1}$ Molecular Biology and Microbiology Department, ${ }^{4}$ Neuroscience Program, and ${ }^{3}$ Department of Neurosurgery, Tufts \\ University School of Medicine, Boston, Massachusetts 02111, 'Laboratory of Molecular Neurobiology, Burke \\ Rehabilitation Center, Cornell University Medical College, White Plains, New York 10605, and ${ }^{5}$ Roche Institute of \\ Molecular Biology, Roche Research Center, Nutley, New Jersey 07110
}

The separation between the cell bodies of olfactory receptor neurons in the nasal cavity and their axon terminals in the olfactory bulb make them attractive for studying axonal transport. Although high molecular weight RNAs are generally believed to be excluded from axons of mature neurons, we demonstrate here that mRNA for olfactory marker protein (OMP), an abundant cytoplasmic protein selectively expressed in mature receptor cells, is present in rodent olfactory receptor axons. OMP RNA was detected by in situ hybridization at the light microscope level in axons and in terminals. By nuclease protection, the level of OMP RNA in the olfactory bulb was $\mathbf{5 - 1 0 \%}$ of that in the olfactory epithelium where the cell bodies reside. In contrast to axonally transported vasopressin and oxytocin mRNAs, which are deficient in their $3^{\prime}$ polyA tails, axonal OMP RNA fractionated as polyA $A^{+}$. OMP RNA was lost from axons and terminals after deafferentation, suggesting that OMP RNA was synthesized in receptor cell bodies in the epithelium and was transported Into axons and terminals in the olfactory bulb. RNA for $\mathrm{G}_{\mathrm{olf}}$, a G-protein highly expressed in dendrites of mature olfactory receptor neurons, was not detected in the olfactory bulb. We hypothesize that the immature nature of the cytoskeleton and, specifically, the lack of tightly bundled microtubules allows transport of particular mRNAs in olfactory receptor axons.

[Key words: olfactory marker protein, olfaction, axonal transport, mRNA, in situ hybridization, olfactory epithelium]

Although most proteins are made in the cell body and transported to different subcellular compartments, some proteins are synthesized from RNAs that are themselves sequestered in discrete subcellular sites. Their specific intracellular localization results from the transport of their mRNAs, which occurs prior to translation. In mammalian neurons, the best examples of local-

Received Nov. 10, 1994; revised Jan 17, 1995; accepted Jan 19, 1995.

This work was supported by NIH Grants NS22675 and NS29676 to D.M.C; DC01710 and AG09686 to H.B.; and DC00228 to J.S.K. We thank Mr. Walter Dent for photography and Ms. Barbara D'Angelo for preparation of the manuscript. We thank Dr. Charles A. Greer for many helpful and stimulating discussions and for reading of the manuscript.

Correspondence should be addressed to Dona M. Chikaraishi, Neuroscience Program, Tufts University School of Medicine, 136 Harrison Avenue, Boston, MA 02111.

Copyright (C) 1995 Society for Neuroscience $0270-6474 / 95 / 154827-11 \$ 05.00 / 0$ ized mRNAs are those encoding microtubule-associated protein 2 (MAP2) and the a subunit of calcium/calmodulin kinase type II (CaMKII) (see Steward and Banker, 1992, for review). MAP2 and CaMKII proteins are localized to mature dendrites and are excluded from axons. Dendritic localization of their RNAs has been demonstrated in vivo in the cerebral cortex and hippocampus (Garner et al., 1988; Burgin et al., 1990) and in cultured primary neurons (Bruckenstein et al., 1990; Kleiman et al.,1990). RNAs encoding other cytoskeletal proteins such as $\beta$ tubulin, $68 \mathrm{kDa}$ neurofilament, and MAP5 remained restricted to the cell body (Garner et al., 1988; Tucker et al., 1989; Kleiman et al., 1990).

Because high levels of MAP2 and CaMKII RNA remain in the cell body, these proteins are likely to be translated both in the cell body and at distant sites. A substantial body of evidence suggests that dendritic RNAs are translated: polyribosomes have been observed in dendrites, especially during periods of synaptogenesis (Steward and Levy, 1982; Steward, 1983) and in vivo and in vitro dendritic elements can incorporate radioactive amino acid precursors into protein (Fass and Steward, 1983; Torre and Steward, 1992). Synaptosomal preparations that include dendritic endings have been shown to synthesize proteins (Autilio et al., 1968; Verity et al., 1980), some of which can be localized to the synaptic plasma membrane and synaptic junctional complex (Rao and Steward, 1991).

Although mRNAs are found in molluscan axons (see Van Minnen, 1994, for review), and tau mRNA has been localized to proximal axon segments in cultured cortical neurons (Litman et al., 1993), in general, mRNAs are not present in mature axons. However, localization of oxytocin, arginine vasopressin (AVP) and tyrosine hydroxylase mRNA has been documented in the axons of hypothalamic paraventricular and supraoptic neurons that terminate in the posterior pituitary. Oxytocin and vasopressin RNAs were detected in the posterior pituitary (Murphy et al., 1989; McCabe et al., 1990) and were lost after transection of the hypothalamo-hypophysial tract (Mohr et al., 1990), suggesting that the RNAs were transported from the cell bodies in the hypothalamus. In situ hybridization showed that oxytocin RNA in lactating rats (Jirikowski et al., 1990) and AVP RNA in salt-loaded rats (Trembleau et al., 1994) were intra-axonal. Northern blot analyses of axonal oxytocin and AVP RNAs showed that they became progressively shorter as they moved down the hypothalamo-hypophysial tract (Mohr et al., 1991). Since previous nucleotide sequence analysis had revealed that 
the mRNAs from the hypothalamus and the posterior pituitary were identical (Mohr et al., 1990), the difference in length was attributed to a progressive shortening of the polyA tail.

It was further shown that AVP RNA injected into the hypothalamo-hypophysial tract could ameliorate the diabetic phenotype of Brattleboro rats that lack endogenous AVP (Jirikowski et al., 1992; Maciejewski-Lenoir et al., 1993). Radiolabeled AVP RNA, taken up in axons, was anterogradely transported to the pituitary and was retrogradely carried back to cell bodies in the hypothalamus, where it was presumably translated. Injected polyA ${ }^{-}$AVP mRNA was 200 -fold more effective than polyA ${ }^{+}$ RNA (Maciejewski-Lenoir et al., 1993), suggesting that shortening of the polyA tail during transport may have functional relevance. These experiments demonstrate that axonal RNAs can be translated, albeit in the cell body, and that RNAs can be efficiently taken up into axons.

Recently, mRNA for a neurotransmitter biosynthetic enzyme, tyrosine hydroxylase (TH), was found in the same hypothalamoneurohypophysial tract, suggesting that axonal transport is not restricted to RNAs encoding secretory proteins (Skutella et al., 1994). Like AVP RNA, TH RNA was retrogradely transported back to hypothalamic cell bodies after salt loading. These results prompted us to ask if axonal localization of RNA was restricted to the hypothalamo-neurohypophysial system in mammals.

The rodent olfactory receptor neuron was chosen as a model since it has been used to study axoplasmic protein transport; its cell bodies and terminals are widely separated, and it synthesizes proteins with a highly restricted cellular distribution. We describe studies on the localization of RNA encoding olfactory marker protein (OMP), a $19 \mathrm{kDa}$, cytoplasmic protein of unknown function whose expression is highly restricted to mature olfactory neurons in many vertebrate species (see Margolis, 1980, for review; Buiakova et al., 1994). In the nasal neuroepithelium, OMP is only found in mature olfactory receptor neurons whose axons terminate in the olfactory bulb (OB). Although low levels of OMP protein have been detected in a few non-olfactory neurons (Baker et al., 1989), there are no OMPpositive cell bodies in the OB (Monti-Graziadei et al., 1980; Baker et al., 1989). Hence, it was surprising that functional OMP RNA could be detected in the olfactory bulb by Northern blot hybridization (Ehrlich et al., 1990) by reverse transcriptase-coupled PCR (Grillo and Margolis, 1990), and by in vitro translation followed by immunoprecipitation (Rogers et al., 1987). These earlier studies, however, did not determine where OMP RNA was localized and could not discriminate between two possibilities. Either OMP RNA could be made in OB cells that did not express OMP protein, or OMP RNA reached the OB by axonal transport from receptor cell bodies in the nasal cavity. In situ hybridization experiments presented here demonstrate that OMP RNA is found in axons and terminals of the olfactory nerve and is lost after peripheral deafferentation. This strongly suggests that OMP RNA reaches the OB by axonal transport. We further show that the transported OMP RNA is polyadenylated, unlike oxytocin and $\Lambda \mathrm{VP}$ transcripts found in hypothalamic axons.

\section{Materials and Methods}

Animal procedures. Anesthetized, 4-week-old Sprague-Dawley male rats were axotomized by drilling a small bore hole over the left olfactory bulb at a position slightly left of the midline and even with the front of the eyes (Kawano and Margolis, 1982). The axons around the left bulb were cut with a curved syringe needle inserted into the bore hole. Axotomized animals were allowed to recover for 10-14 d. After they were humanely killed, the animals were examined to determine if axotomies were successful. Bilateral deafferentation of mouse olfactory bulbs were performed as described (Kawano and Margolis, 1982). A 25 gauge syringe needle was filed to a blunt tip $3 \mathrm{~mm}$ long. The end was inserted into the left naris of an unanesthetized adult CD1 mouse, which was held by hand. The nasal cavity was irrigated with $100 \mu l$ of $0.17 \mathrm{M}$ $\mathrm{ZnSO}_{4}$. The animals were kept for $7 \mathrm{~d}$ before humanely killed. The olfactory epithelium was histologically examined to determine that deafferentation was successful.

Probe preparation. Single-stranded riboprobes were made according to Melton et al. (1984), using $\alpha^{32}$ P-UTP (Ncw England Nuclear; 800 $\mathrm{Ci} / \mathrm{mmol}$ ) and $1 \mu \mathrm{g}$ of plasmid DNA. Unincorporated nucleotides were removed on a $1 \mathrm{ml}$ Sephadex G50 column. OMP riboprobe was prepared from a PstI-BamHI fragment (containing nucleotides 185 to 892) of pOMP (Rogers et al., 1987) that had been subcloned into pSP65 and was recloned into Bluescript SKM13- (Stratagene, La Jolla, CA) at the PstI and BamHI sites. The resulting plasmid was linearized with StuI at nucleotide 715 , and sense probe was transcribed from the T3 promoter; antisense from the $\mathrm{T} 7$ promoter. $\mathrm{G}_{\text {oft }}$-Bluescript plasmid (Jones and Reed, 1989) was the generous gift of Dr. Randy Reed (Johns Hopkins School of Medicine) contained a 3.0 EcoRI fragment of $G_{\text {olf }}$. Circular DNA was used for riboprobe preparation; antisense was transcribed from the $\mathrm{T} 7$ promoter, sense from the $\mathrm{T} 3$ promoter. Riboprobe preparation from the first exon of rat tyrosine hydroxylase $(\mathrm{TH})$ plasmid pAA360 was previously described (Fung et al., 1991).

In situ hybridization. Deeply anesthetized adult rats or mice were intracardially perfused; dissected olfactory epithelia and bulbs were subjected to in situ hybridization as described (Simmons et al., 1989) using 10 micron frozen sections. Hybridization was performed at $55^{\circ} \mathrm{C}$ overnight using ${ }^{32}$ P-labeled riboprobes at $1.25 \times 10^{6} \mathrm{cpm}$ per ml. After hybridization, the slides were exposed to NTB-2 (Kodak, Rochester, NY) emulsion diluted 1:1 with water. After the liquid emulsion dried, slides were exposed at $-80^{\circ} \mathrm{C}$. After developing, sections were stained for $5 \mathrm{~min}$ with $5 \times 10^{-5} \mathrm{M}$ Hoechst dye 33258 (Aldrich Chemical, Milwaukee, WI) and rinsed briefly with distilled water before mounting. In all figures except $5 C$, the data are presented as the same field shown both under fiuorescence to detect Hoechst-stained nuclei and under dark field to detect autoradiographic grains.

In situ hybridization combined with immunocytochemistry. Sections were prepared from 28-month-old Fischer 344 rats and were subjected to in situ hybridization using ${ }^{35} \mathrm{~S}$-labeled rat OMP probe and immunocytochemistry to tyrosine hydroxylase as described (Stone et al.1991).

RNA preparation and nuclease protection assays. Total RNA from freshly dissected adult rat olfactory bulbs, epithelia, and liver was prepared using $6 \mathrm{~m}$ urea $/ 3 \mathrm{~m} \mathrm{LiCl} / 10 \mathrm{~m} \mathrm{~m}$ vanadylribonucleoside complex (Bethesda Research Labs, Grand Island, NY), as described by Fung et al. (1991). When dissecting the olfactory bulb, the cribiform plate remained intact, and only tissue posterior to the plate was removed. PolyA $^{+}$and polyA ${ }^{-}$RNA was prepared as described by Fung et al. (1991), except a single cycle of purification on oligo-dT cellulose was performed. After one round of selection on oligo-dT cellulose, between $4 \%$ and $6 \%$ of the total RNA eluted as poly $\mathrm{A}^{+}$. Given that polyA $\mathrm{A}^{+}$ RN $\Lambda$ represents about $2 \%$ of the total RNA in most tissues, this fractionation is a $18-25 \times$ enrichment for polyA ${ }^{+}$RNA. Nuclease protection assays were performed as described (Fung et al., 1991) using $2-4 \times$ $10^{4} \mathrm{cpm}$ of TH or OMP antisense probe.

\section{Results}

OMP RNA is present in the distal axon segment and terminals of the olfactory nerve in the olfactory bulb

OMP is only expressed in mature sensory neurons in the $\mathrm{OE}$, where it comprises $0.1-1 \%$ of the total protein and $0.5 \%$ of the mRNA (Rogers et al., 1985). OMP is found throughout the cell including proximal dendritic processes, axons, and terminals (Farbman and Margolis, 1980; Monti-Graziadei et al.,1980). Olfactory receptor neurons are unique in that they are continually generated throughout the life of the animal (for review, see Crews and Hunter, 1994). In mature animals they occupy the upper two-thirds of the sensory or olfactory epithelium (OE) and are absent from adjacent regions of respiratory epithelium which, together with the olfactory epithelium, comprise the lining of the nasal cavity. Receptor neurons arisc from an OMPnegative precursor cell located in deep layers of the epithelium 

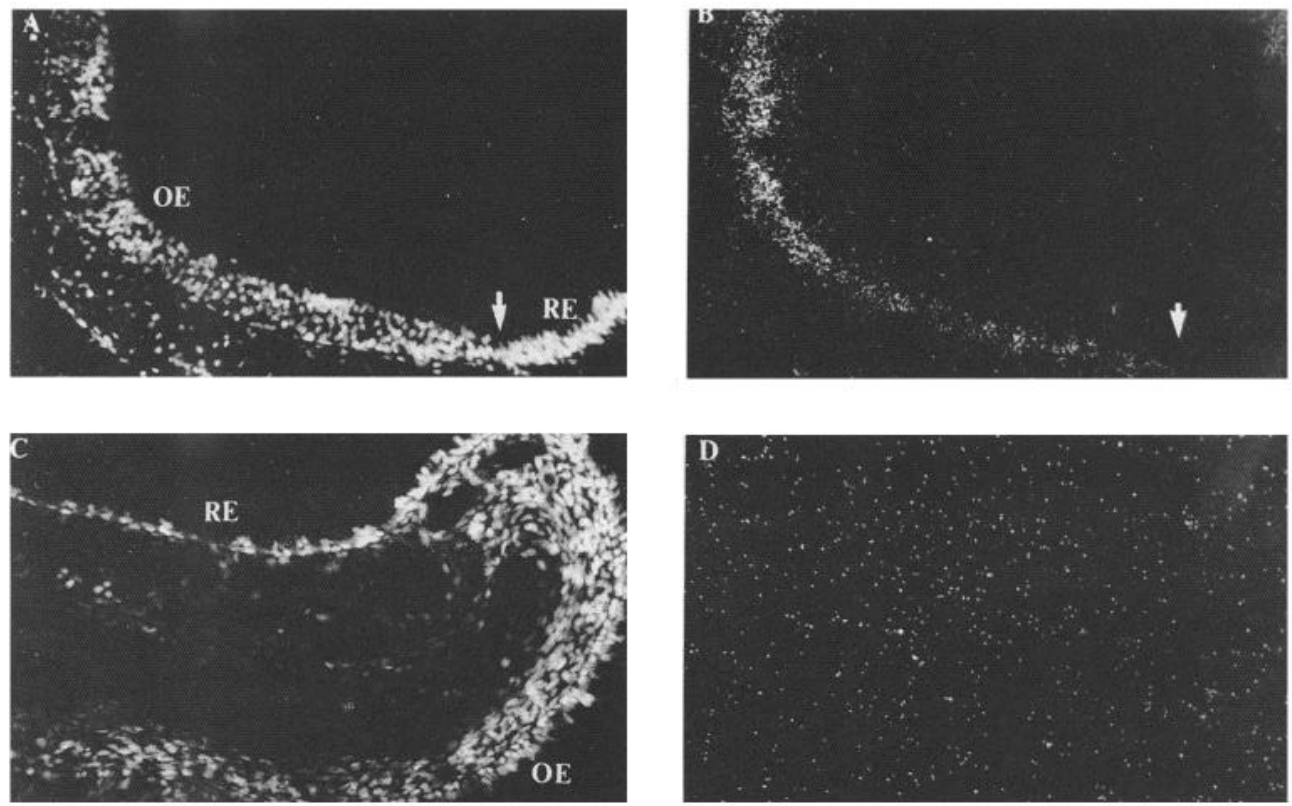

Figure 1. OMP RNA in the olfactory epithelium. Matched fluorescence $(A$, $C$, and $E$ ) and dark-field $(B, D$, and $F)$ photographs of coronal sections of rat nasal cavities hybridized with OMP riboprobe. $A$ and $B$, Adult olfactory epithelium $(O E)$ and respiratory epitheli-
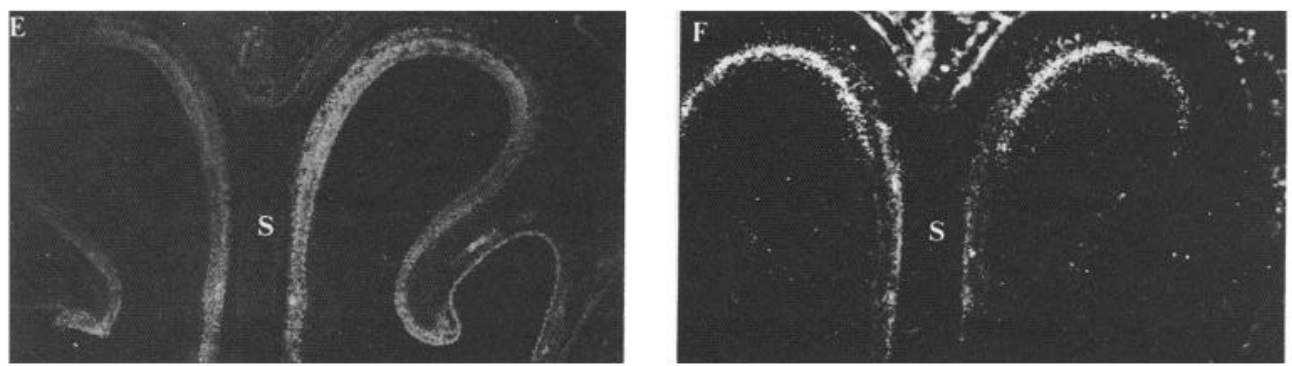
um $(R E)$ hybridized with antisense OMP. Junction between the OE and RE is marked with an arrow. $C$ and $D$, Adult $\mathrm{OE}$ and RE hybridized with sense OMP probe. $E$ and $F$ ) Postnatal day 3 nasal cavity hybridized with antisense OMP probe. In $F$, some autofluorescence of bone above septum $(S)$ is apparent. Exposure times: $B, 5 \mathrm{~d} ; D$, $2.5 \mathrm{~d} ; F, 2.5 \mathrm{~d}$. Magnification: $A$ and $B, 170 \times ; C$ and $D, 340 \times ; E$ and $F$, $68 \times$.

near the basement membrane. As they move into superficial layers, they mature into OMP-positive bipolar neurons whose dendrites develop a terminal knob that possesses modified cilia that extend into the nasal cavity and bear proteins specialized to detect odors. Their unmyelinated axons traverse the basement membrane into the lamina propria and fasciculate into bundles that cross into the cranium through perforations in the cribiform plate of the ethmoid bone. The axons spread over the surface of the olfactory bulb (OB) that they penetrate to synapse with second-order neurons in complex glomerular structures that are circumperipheral to the olfactory bulb. The relatively long distance between cell bodies in the nasal cavity and axon terminals on the opposite side of the cribiform plate make these neurons easily amenable to biochemical experiments that require dissection of cell bodies away from terminals.

To validate the specificity of in situ hybridization with the rat OMP riboprobe, coronal sections of adult rat olfactory epithelium (OE) were hybridized with antisense OMP probe. As expected, we detected robust hybridization in the outer two-thirds of the sensory portion of the $\mathrm{OE}$, where mature receptor cells reside (Fig. 1A,B). The hybridization signal stops at the border between the sensory and respiratory epithelium (RE) (indicated by an arrow) and is absent from the RE. It is also absent from the lamina propria beneath the epithelium. Hybridization to coronal sections of 3 -d-old rats (Fig. $1 E, F$ ) confirms that OMP is present in early postnatal animals and that the expression is largely confined to the dorsal region of the nasal cavity. These data demonstrate that the OMP probe appropriately hybridizes to receptor neurons, the only cells in the OE known to express OMP protein. Similar experiments with mouse OE yielded the same results, confirming that the rat OMP probe cross-hybridizes with mouse OMP RNA (data not shown). Sense strand OMP riboprobe gave no signal with $\mathrm{OE}$ sections (Fig. $1 C, D$ ).

Figures $2, A$ and $B$, and $3 A$ demonstrate that OMP hybridization could be detected in the olfactory nerve layer (NL) of the OB. This region contains the distal segments of the olfactory receptor axons. Under higher magnification (Figs. $2 C, D ; 3 B$ ), the signal can be seen extending into individual glomeruli $(G)$, where the terminals of receptor neurons synapse. In contrast, the next deeper layer of the bulb, the external plexiform layer (EPL), is essentially free of grains. The fact that labeling extends into glomeruli suggests that OMP RNA is present in presynaptic terminals. Figure 3, $C$ and $D$, demonstrates that the grains do not cover the TH positive neurons that surround the glomeruli, suggesting that the RNA is restricted to receptor cell terminals in the glomerular neuropil. Sense strand OMP riboprobe gave no signal (Fig. 2E,F).

\section{RNA for $G_{\text {olf }}$ is not localized in the axons and terminal of receptor neurons in the olfactory bulb}

To determine if other RNAs expressed in olfactory receptor neurons were also transported to the bulb, the distribution of $\mathrm{G}_{\text {olf }}$ RNA was examined. $\mathrm{G}_{\text {ofl }}$ is a Gs-like $\alpha$ subunit that is abundant in the OE. The protein is concentrated in sensory cilia where it is thought to transduce odorant-induced signals from olfactory receptors to activate adenylate cyclase. Like OMP, $\mathrm{G}_{\text {olf }}$ protein 

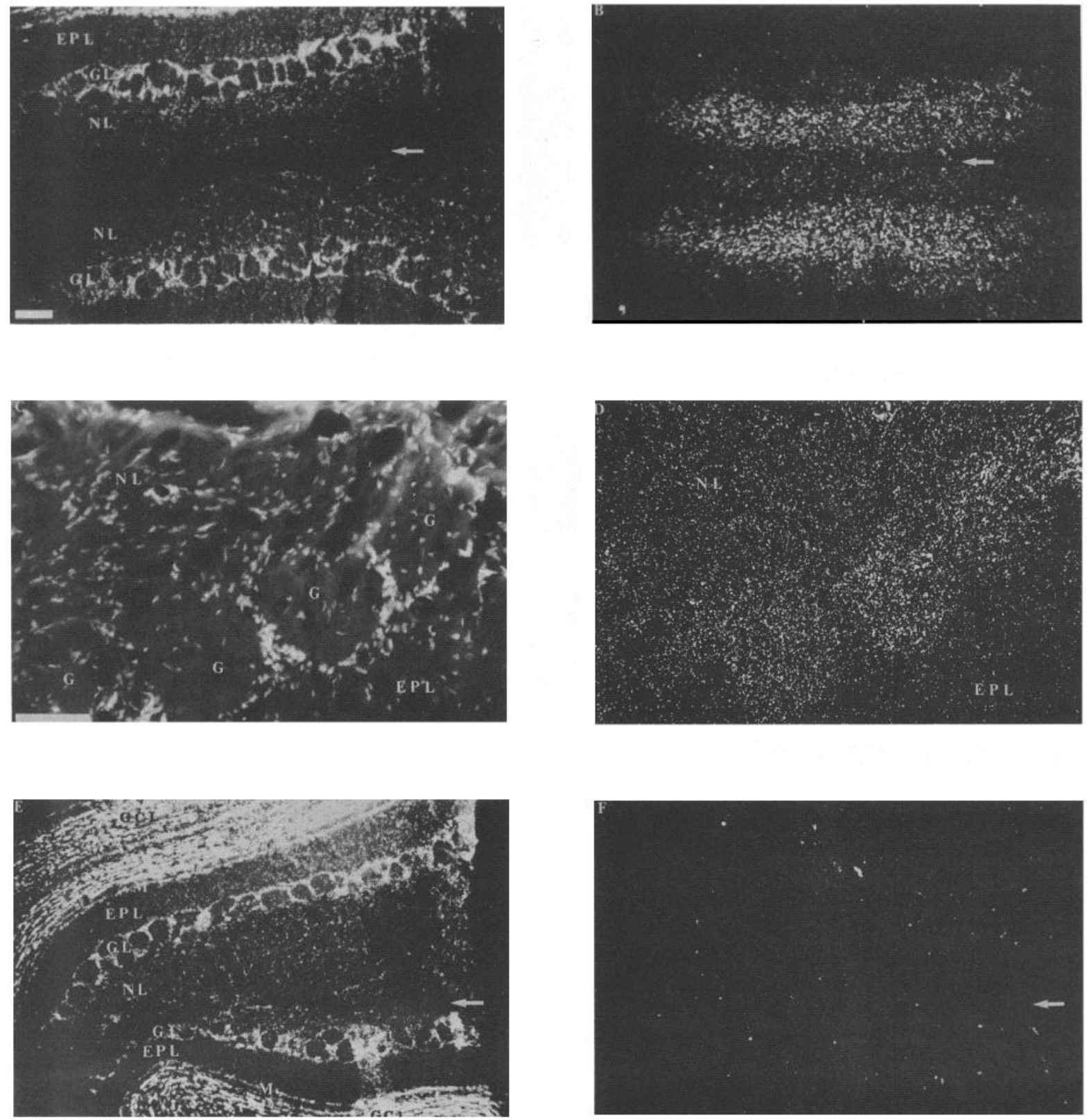

Figure 2. OMP RNA in normal olfactory bulbs. Matched fluorescence $(A, C$, and $E)$ and dark-field $(B, D$, and $F)$ photographs of coronal sections of rat olfactory bulbs hybridized with OMP riboprobe. $A$ and $B$, Hybridization with antisense probe. Arrow demarcates the separation between the pair of OBs. $C$ and $D$, Higher magnification of the glomerular layer hybridized with antisense probe. $E$ and $F$, Hybridization with sense probe. Arrow demarcates separation between the pair of OBs. $G C L$, granule cell layer; $E P L$, external plexiform layer; $G L$, glomerular layer; $N L$, olfactory nerve layer; $G$, glomerulus. Exposure times: $B, 4.5 \mathrm{~d} ; D, 4.5 \mathrm{~d} ; F, 7 \mathrm{~d}$. Scale bar: $A, B, E$, and $F, 200 \mu \mathrm{m} ; C$ and $D, 100 \mu \mathrm{m}$.

has been shown by immunocytochemistry of the $\mathrm{OE}$ to be expressed only in receptor neurons (Jones and Reed, 1989). Figure 4 demonstrates that $\mathrm{G}_{\text {off }}$ RNA can be detected by in situ hybridization in the neuroepithelium, but cannot be detected in the olfactory bulb (Fig. 5), although its RNA in the OE is at least as abundant as OMP RNA (Jones and Reed, 1989). The low level of silver grains in deeper layers of the bulb (granule cell layer) is likely to be due to cross-hybridization with other Gs RNAs in those regions. Nevertheless, there was no detectable hybridization over the olfactory nerve or glomerular layers even

Figure 3. Colocalization of OMP mRNA and TH protein in rat olfactory bulb. Dark-field photographs of OMP mRNA demonstrated by in situ hybridization at low $(A)$ and high $(B)$ magnification. Hybridization signal occurs in fibers in the nerve layer $(N)$ and within glomeruli $(G)$. Arrow in $A$ indicates similar region illustrated at higher magnification (arrow) in $B$. The dark-field photograph in $C$ shows that TH immunoreactivity surrounds the OMP-labeled glomeruli. The arrow indicates the area shown in the bright-field photograph, $D$. As evident in $D$, grains do not occur over TH positive cell bodies or in the external plexiform layer $(E)$ to the left of the glomeruli. $M$, mitral cell layer, $G r$, granule cell layer. Scale bar: $500 \mu \mathrm{m}$ in $A ; 150 \mu \mathrm{m}$ in $B ; 50 \mu \mathrm{m}$ in $C ; 25 \mu \mathrm{m}$ in $D$. Exposure time for all sections was $14 \mathrm{~d}$. 

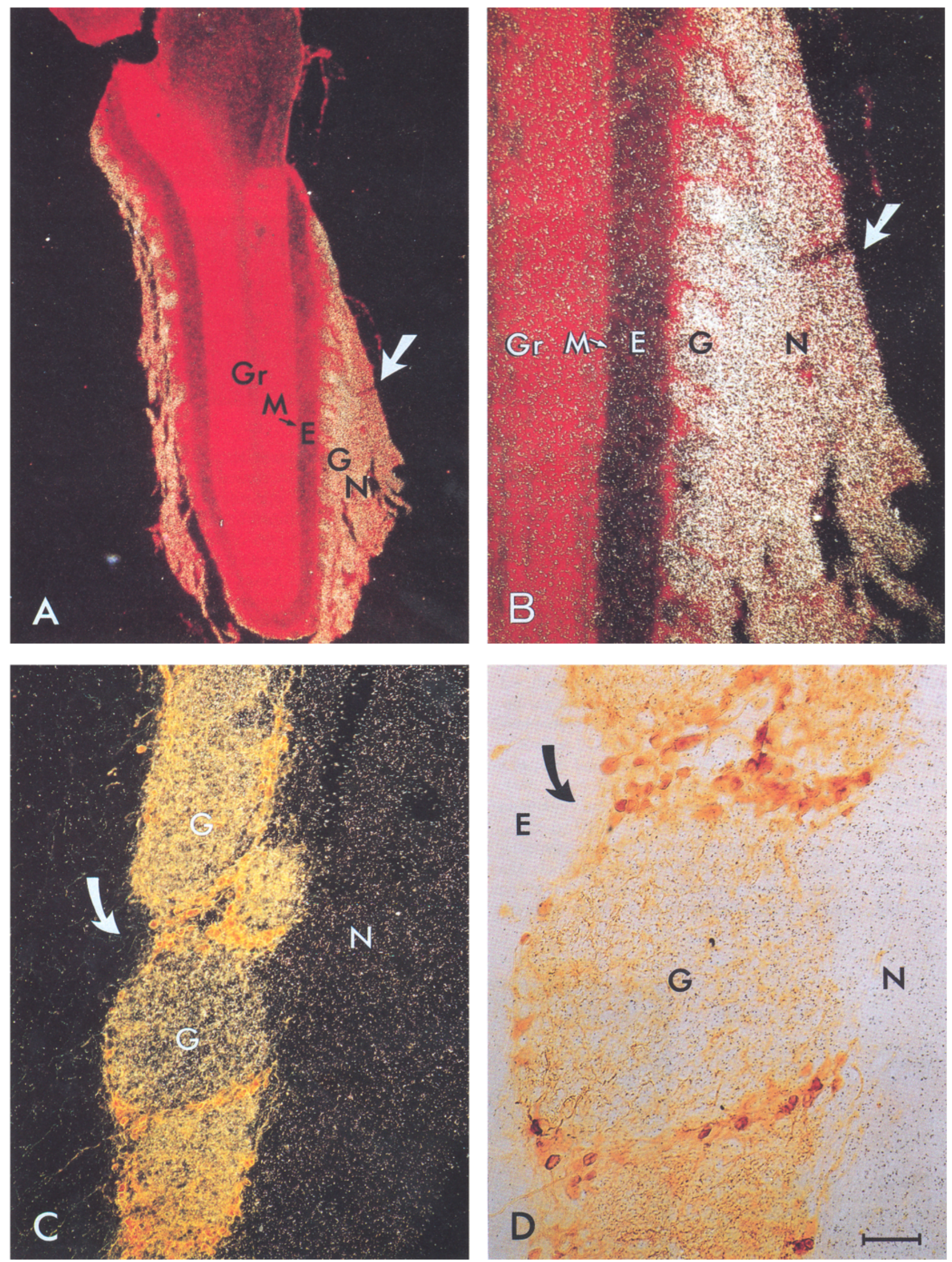

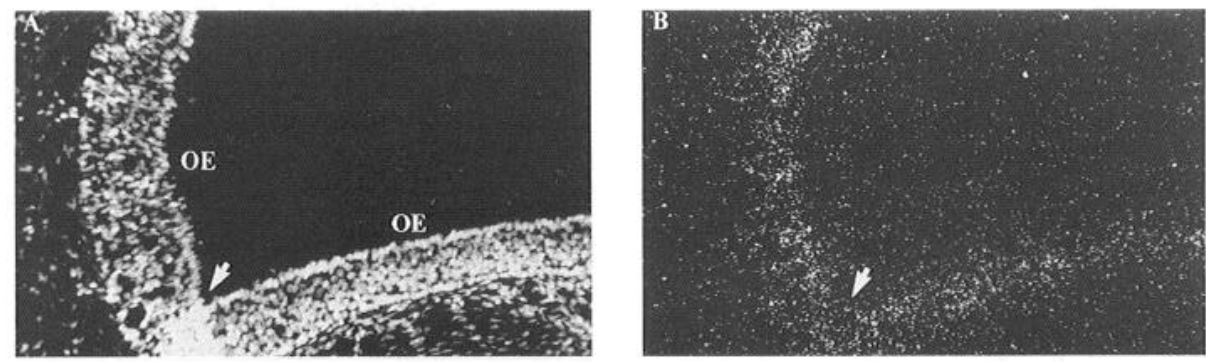

Figure 4. $\mathrm{G}_{\text {olf }}$ RNA in the olfactory epithelium. Matched fluorescence $(A$ and $C)$ and dark-field $(B$ and $D)$ photographs of coronal sections of rat nasal cavities hybridized with $\mathrm{G}_{\text {orf }}$ riboprobes. $A$ and $B$, Hybridized with antisense probe. Fold in the olfactory epithelium $(O E)$ is noted with an arrow. $C$ and $D$, Hybridized with sense probe. Exposure for $B$ and $D, 6 \mathrm{~d}$. Magnification, $210 \times$.
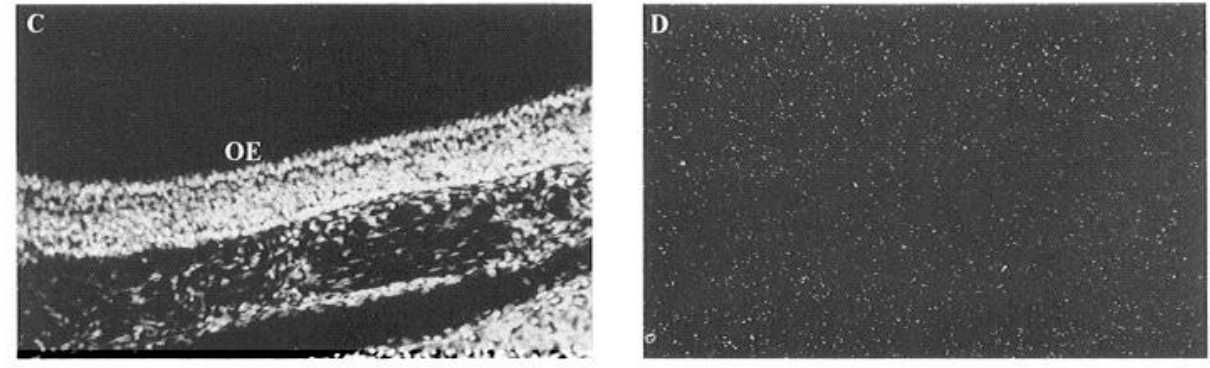

at exposure times longer than those used for OMP hybridization in the bulb. Likewise, no hybridization was observed with a NCAM (neural cell adhesion molecule) probe in the outer bulb layers, although signal was detected in receptor neurons and in deep layers of the bulb (data not shown). These data demonstrate that not all mRNAs are localized to axons and terminals of olfactory receptor neurons.

\section{Deafferentation by $\mathrm{ZnSO}_{4}$ lavage or axotomy induces loss of} $O M P R N A$ from the olfactory bulb

If OMP RNA is initially transcribed in the nuclei of receptor neurons in the $\mathrm{OE}$ and is axonally transported to the bulb, the RNA should be lost if receptor neurons or their axons are destroyed. Hence, we induced deafferentation by two procedures. First, adult mice were intranasally irrigated with $0.17 \mathrm{M} \mathrm{ZnSO}_{4}$, a procedure known to irreversibly destroy mature and immature neurons as well as support cells in the OE (Nadi et al., 1981; Burd, 1993). In our experiments, destruction of the epithelium was complete and bilateral, as determined by histological examination. Seven days after lavage, OMP RNA was undetectable in terminal fields of the olfactory bulb (Fig. 6A,B). In situ hybridization of control mice irrigated with saline showed no loss of OMP signal from the OE and olfactory bulbs (data not shown).
Because $\mathrm{ZnSO}_{4}$ treatment destroys both sides of the epithelium, unilateral axotomy was used to lesion only one side of the epithelium, leaving the opposite side intact. The drawback of axotomy is that it is difficult to achieve complete lesioning, especially at the medial border of the bulb. Axotomy induces retrograde degeneration of mature receptor neurons whose axons have been lesioned, but leaves other cells in the OE intact. We performed in situ hybridization on rats 10 to $14 \mathrm{~d}$ after unilateral axotomy. OMP RNA disappeared from the lateral portion of the axotomized bulb and was significantly reduced medially (Fig. $6 C$ ). The nonaxotomized side retained strong OMP hybridization, both laterally and medially. At higher magnification (Fig. $6 D, E)$, it is evident that all OMP signal is lost from the lateral olfactory nerve and glomerular layer, while some residual signal remains on the medial side, probably due to incomplete axotomy. Both methods of deafferentation reduce or ablate OMP hybridization in the olfactory bulb, consistent with the notion that OMP RNA is transported into the bulb from perikarya of receptor neurons in the OE.

\section{Quantification of OMP RNA in the olfactory bulb by nuclease protection}

Because of the difficulty in quantifying in situ hybridization from different tissues (OE vs $\mathrm{OB}$ ), we performed solution hy-
Figure 5. $\mathrm{G}_{\text {olr }}$ in the olfactory bulb. Matched fluorescence $(A)$ and darkfield $(B)$ photograph of a coronal section of rat $O B$ hybridized with $\mathrm{G}_{\text {olf }}$ antisense riboprobe followed by exposure for $7 \mathrm{~d}$. Scale bar, $200 \mu \mathrm{m}$.
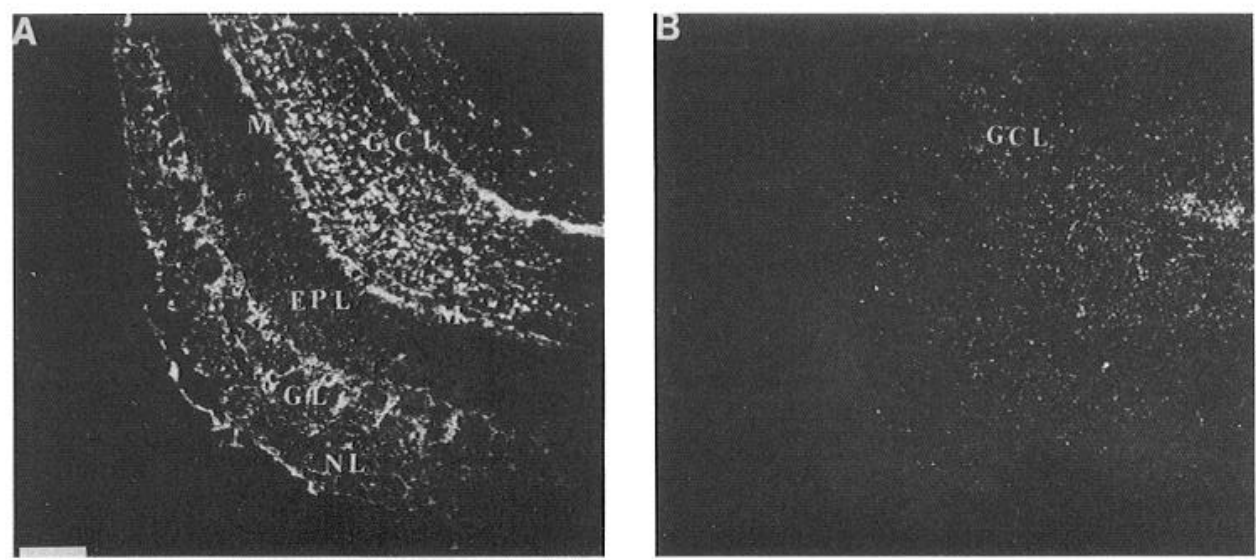

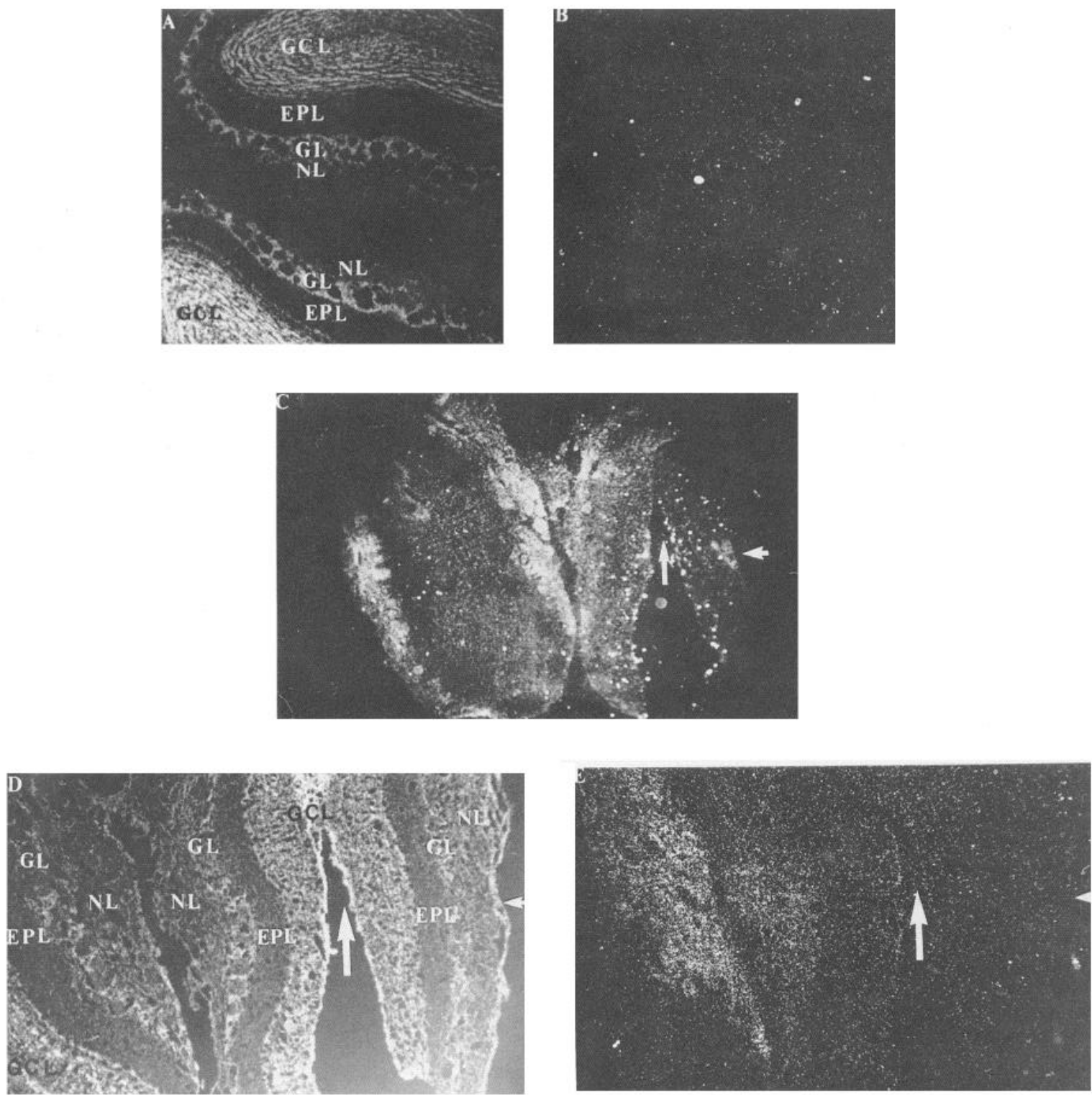

Figure 6. Chemical deafferentation with $\mathrm{ZnSO}_{4}$ and unilateral axotomy induce loss of OMP RNA in the olfactory bulb. Matched fluorescence ( $A$ and $D$ ) and dark-field $(B$ and $E$ ) photographs of sections of olfactory bulb hybridized with antisense OMP riboprobe. $A$ and B, Mouse olfactory bulbs from $\mathrm{ZnSO}_{4}$-treated animals. Note the lack of hybridization signal. $C$, Low-magnification dark-field photograph of in situ hybridization of rat olfactory bulb after axotomy of the right OB. Hybridization is present on both lateral and medial border of intact bulb but is lost on the lateral border and reduced on the medial portion of axotomized bulb. Tear in the axotomized bulb is indicated with an arrow. Arrowhead marks the lateral edge of the axotomized bulb. $D$ and $E$, Another section shown at higher magnification. Tear in the GCL of the axotomized bulb is indicated with arrow; lateral edge of axotomized bulb is indicated with an arrowhead. $G C L$, granule cell layer; $E P L$, external plexiform layer; $G L$, glomerular layer; $N L$, olfactory nerve layer. Exposure times: $B, 4 \mathrm{~d} ; C$ and $E, 5 \mathrm{~d}$. Magnification: $A, B, D$, and $E, 70 \times ; C, 35 \times$.

bridization to determine the amount of OMP RNA in the olfactory bulb under conditions in which the intensity of hybridization signal is proportional to the amount of RNA in a sample. When OMP riboprobe was annealed to total rat OE or olfactory bulb RNA, a nuclease-protected band at 183 base pair (bp) was detected, the size expected for OMP RNA (Fig. 7). We estimate from the data in Figure 7 and other similar experiments that OMP RNA in the olfactory bulb is about $5-10 \%$ the level found in the olfactory epithelium. Similar estimates were obtained from previous Northern blot data (Ehrlich et al., 1990). Our estimate represents a lower limit, since OMP RNA in regions of the nerve not associated with the bulb (e.g., within the cribiform plate) are not included. Nevertheless, it is likely that only a small proportion of the total OMP mRNA is transported. In agreement with the in situ hybridization data, RNA extracted from axotomized olfactory bulbs lacked OMP sequences, as did liver and tRNA samples included as negative controls (Fig. 7).

\section{Transported OMP RNA fractionates as polyA ${ }^{+}$}

As axonally transported oxytocin and AVP RNAs were reported to be deficient in their polyA tails, we determined whether OMP RNA in the olfactory bulb was polyadenylated. Total olfactory bulb RNA was fractionated over an affinity oligo-dT cellulose column into poly $\mathrm{A}^{+}$and polyA ${ }^{-}$fractions. PolyA ${ }^{+}$and poly $\mathrm{A}^{-}$ RNA from the same preparation and equivalent to the same amount of starting tissue (i.e., four olfactory bulbs) was hybrid- 


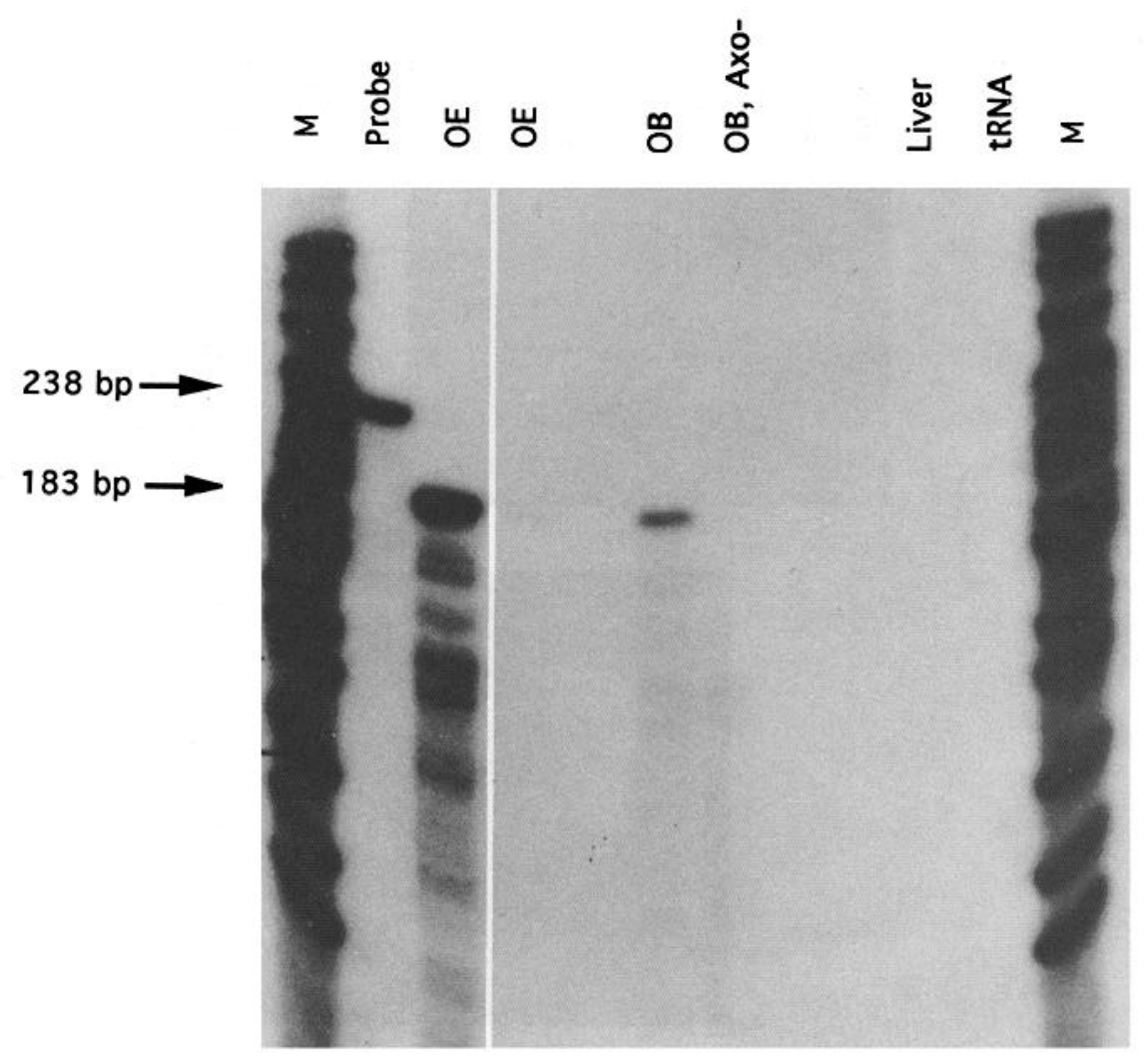

Figure 7. Quantification of OMP RNA by nuclease protection. OMP riboprobe was annealed to rat RNAs and analyzed as described in Material and Methods. The undigested probe is 238 $\mathrm{bp}$, while the size of protected by OMP mRNA is 183 bp. Lanes $I$ and 9, DNA markers $(M)$ of pBR322 DNA digested with MspI; lane 2, undigested OMP riboprobe; lane $3,10 \mu \mathrm{g}$ olfactory epithelium (OE) RNA; lane 4, $0.1 \mu \mathrm{g} \mathrm{OE}$ RNA; lane 5, $10 \mu \mathrm{g}$ olfactory bulb (OB) RNA; lane 6, $10 \mu \mathrm{g}$ olfactory bulb RNA after axotomy (OB, axo-); lane 7, $10 \mu \mathrm{g}$ liver RNA; lane 8, 10 $\mu \mathrm{g} E$. coli tRNA.

ized to OMP riboprobe. As shown in the right panel of Figure $8,80-90 \%$ of the OMP RNA fractionated as polyA ${ }^{+}$. To assess to what extent the small amount of polyA- OMP RNA was due to random degradation and/or incomplete fractionation, we de- termined what percentage of an endogenous poly $\mathrm{A}^{+}$RNA fractionated as poly $\mathrm{A}^{-}$in the same RNA samples. For this purpose, we used tyrosine hydroxylase RNA, which is a polyA ${ }^{+}$RNA synthesized by $\mathrm{OB}$ juxtaglomerular neurons and is about the
Figure 8. The majority of OMP RNA in the olfactory bulb is poly $\mathrm{A}^{+}$. Rat olfactory bulb (OB) RNA was fractionated into polyA $\mathrm{A}^{+}$or poly $\mathrm{A}^{-}$fractions on oligo-dT cellulose and annealed with riboprobes for OMP (right panel) or tyrosine hydroxylase (left panel) and analyzed as described in Materials and Methods. Left panel, lane 1 (tRNA), $50 \mu \mathrm{g}$ E. coli tRNA; lane 2 (total RNA), $35.3 \mu \mathrm{g}$ of total OB RNA (equivalent to the amount of total RNA from one rat); lane 3 ( $\left.A^{-} R N A\right), 64.2$ $\mu \mathrm{g}$ of polyA- OB RNA (equivalent to RNA from two rats); lane $4\left(A^{+} R N A\right)$, $4.1 \mu \mathrm{g}$ of polyA ${ }^{+}$OB RNA (equivalent to RNA from two rats); lane $5(M)$, DNA markers. The expected size of the hybridized TH mRNA band is $125 \mathrm{bp}$, which represents the first exon. Right panel: lanes 1 and $2(M)$, DNA markers; lanes 3 and 4 (probe), undigested OMP riboprobe; lane $5(t R N A), 50 \mu \mathrm{g}$ of $E$. coli tRNA; lane 6 (total RNA), $35.3 \mu \mathrm{g}$ of total OB RNA; lane $7\left(A^{-}\right.$ $R N A), 64.2 \mu \mathrm{g}$ of polyA ${ }^{-} \mathrm{OB}$ RNA; lane $8\left(A^{+} R N A\right), 4.1 \mu \mathrm{g}$ of polyA ${ }^{+} \mathrm{OB}$ RNA.
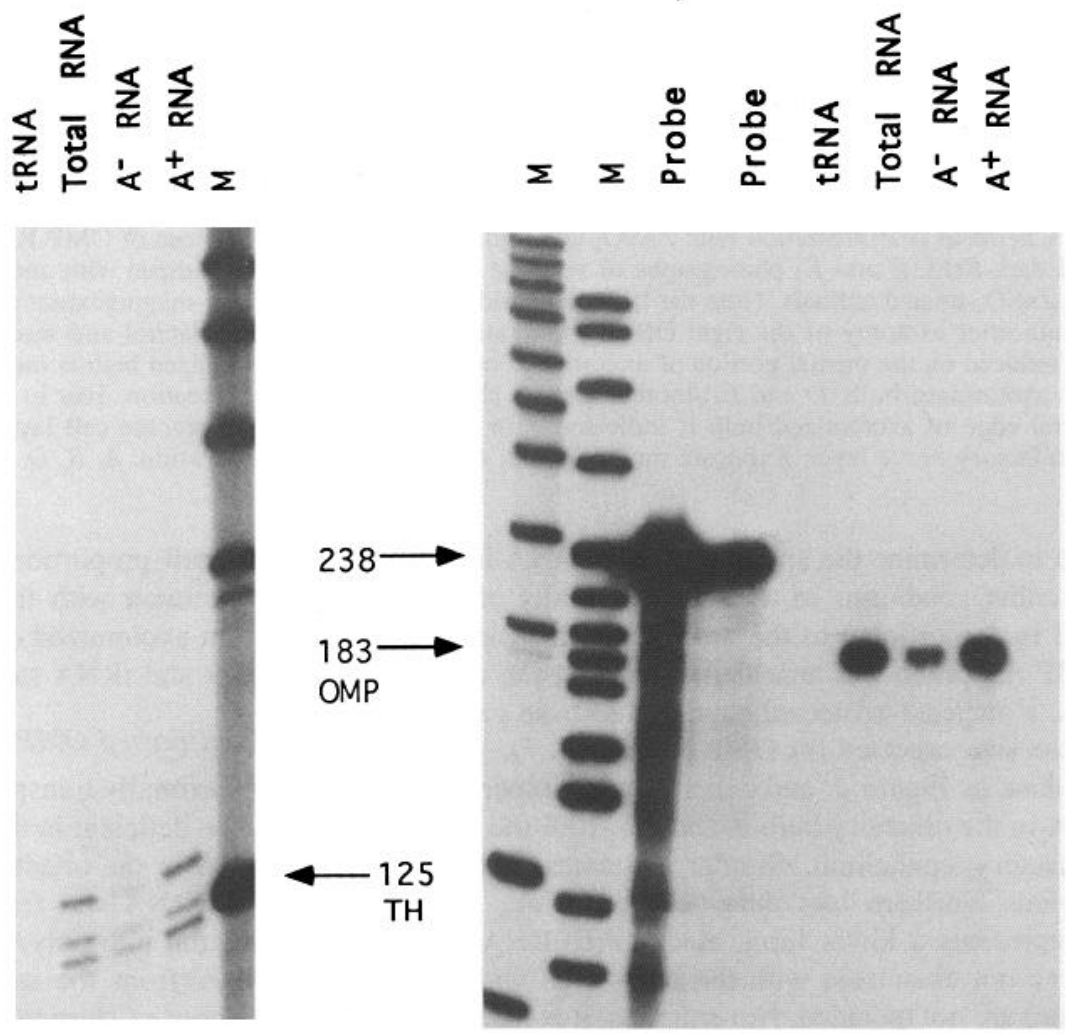
same size as OMP RNA (TH RN $\Lambda$ is $2.0 \mathrm{~kb}$, OMP is $2.3 \mathrm{~kb}$ ). As seen in the left panel of Figure 8 , about the same proportion of TH RNA fractionates as polyA-. These results were obtained from three different RNA preparations. These data suggest that OMP RNA in the bulb is poly $\mathrm{A}^{+}$and support earlier Northern blot analysis showing that OMP RNA was purified as poly ${ }^{+}$ RNAs from the OE and olfactory bulb (Ehrlich et al., 1990; Stone et al., 1991). However, these data do not exclude the possibility that the OMP RNA is partially deadenylated during transport, hut enough polyA remains to bind to the affinity column and the reduction in size is too minor to be detected by Northern blots.

\section{Discussion}

This report demonstrates that OMP RNA exists in distal segments of rodent olfactory nerve. OMP RNA was detected by in situ hybridization using radiolabeled probes and autoradiography at the light microscope level. Although this method lacks sufficient resolution to allow definitive intra-axonal localization, we have combined this with biological evidence to support the contention that OMP is axonally located. Thus, the OMP RNA signal is present in the region of the $\mathrm{OB}$ that contains arriving axons and their synaptic terminals and is lost following peripheral deaffercntation or olfactory nerve axotomy. These result are similar to those recently described by Vassar et al. (1994) and Ressler et al. (1994), who showed that OMP and/or olfactory receptor RNAs were found in the $\mathrm{OB}$ and could be reduced by peripheral deafferentation. Peripheral deafferentation results in degeneration of olfactory axons and their terminals but not associated glia (Burd, 1993). These observations are consistent with biochenical sludies demonstrating functional OMP RNA in the OB (Rogers et al., 1987; Ehrlich et al., 1990; Grillo and Margolis, 1990). Although OMP RNA is easily detected in distal nerve segments that surround the $\mathrm{OB}$ and in their synaptic terminals in the glomerular layer, we were unable to observe OMP RNA in proximal axon bundles in the lamina propria even at exposures times longer than those used to detect OB signals. We conclude that the level of OMP RNA in proximal axons is below that of the distal segments, suggesting that there may be an increasing proximal to distal gradient of transported OMP RNA. The fact that we could not detect transport of $G_{\text {olf }}$ RNA, which is as abundant as OMP RNA in the OE, suggests that not all RNAs are transported. However, a recent report has shown that another RNA, that encoding CGRP (calcitonin gene-related peptide), may be present in the mouse olfactory nerve surrounding the OB during embryonic development (Denis-Donini et al., 1993). Hence, as with dendritic RNAs, specific RNAs such as those encoding OMP, olfactory receptors and CGRP may be targeted for axonal transport.

If OMP RNA in the nerve and glomerular layer were not transported via axons, the only local source for RNA would be glia that surround olfactory axons in the olfactory nerve and intermingle with terminals in glomerular neuropil that is devoid of neuronal cell bodies. To our knowledge, OMP has never been localized to glia by immunocytochemistry. Hence, if OMP RNA exists in glia, it is not translated there to any detectable level. It is possible that glial OMP RNA could be imported into adjacent olfactory axons. Precedent for glial-axonal RNA import exists in the squid giant axon. Menichini et al. (1990) recovered labeled tRNA, rRNA, and mRNA in axoplasm when the squid giant axon, free of neuronal cell bodies but with its glial sheath attached, was incubated with tritiated uridine. The authors con- cluded that glial-axonal RNA transfer was the only possible source for the labeled axoplasmic RNAs. However, the giant axon may be unusual in that proteins are also efficiently and robustly transferred from glia to the axons (Gainer et al., 1977). If OMP RNA is synthesized in glia, synthesis by two different types of glia must be invoked, since the glia that ensheathe the axons in the nerve layer are distinct from those in the glomeruli of the OB proper (Barber and Lindsay, 1982; Vollrath et al., 1985; Pixley, 1992; Doucette, 1993). Most importantly, if OMP RNA is made in glia, this synthesis requires the presence of an intact axon, since deafferentation abolishes the in situ hybridization signal and the biochemical detection of OMP RNA by nuclease protection. Thus, the most parsimonious interpretation of our data is that OMP RNA is synthesized in the nuclei of receptor neurons in the $\mathrm{OE}$ and is axonally transported to terminals in the OB.

The function of axonal RN $\Lambda \mathrm{s}$ is unknown. Jirikowski et al. (1990) suggested that axonal oxytocin RNA could represent a storage compartment or be secreted. The in situ hybridization signal from OMP RNA extends into glomeruli, where receptor axons terminate on output mitral neurons and juxtaglomerular neurons. This suggests that OMP RNA may be present in presynaptic processes in a position where it could be released. Although oxytocin RNA was found in large granular secretory vesicles in neurohypophysial terminals (Jirikowski et al., 1990), it is unknown whether oxytocin RNA (or any axonal RNA) is secreted by neurons. Possibly, as suggested by Skutella et al. (1994) for TH mRNA in the hypothalamo-neurohypophysial tract, OMP RNA could be retrogradely transported back to receptor cell bodies as a signaling mechanism.

Although OMP RNA extracted from the OB could be translated in vitro (Rogers et al., 1987), we have no evidence in vivo that OMP protein is synthesized in axons or in terminals. To date, there have been no reports documenting ribosomes in distal segments of mature mammalian axons. In contrast to the lack of protein synthesis in mammalian axons, protein synthesis does occur in the goldfish Mauthner axon (Koening, 1991) and in the squid giant axon (Giuditta et al., 1991; Crispino et al., 1993). However, the experiments in which AVP RNA, injected into axons, amcliorated the diabctic condition of Brattleboro rats, suggests that axonal RNAs can be efficiently translated, presumably after retrograde transport, back into cell bodies (Jirikowski et al., 1992; Maciejewski-Lenoir et al., 1993). Hence, axonal RNAs can be translated, albeit in the perikarya, in mammalian neurons.

OMP RNA has an unusually long $3^{\prime}$ untranslated region: its $3^{\prime}$ untranslated region ( $1630 \mathrm{bp}$ ) is 3.5 -fold longer than its protein coding region (486 bp) (Rogers et al., 1987). This is potentially relevant because all known signals that localize RNAs to discrete subcellular sites are found in the $3^{\prime}$ untranslated regions (Singer, 1993). Localization signals are presumed to be bound by unidentified proteins. The resulting ribonucleoprotein complexes, perhaps associated with a small, noncoding RNA called BC1 (Tiedge et al., 1991, 1993), are transported and anchored by microfilaments and/or microtubules (Singer et al., 1989; Yisraeli et al., 1990; $\Lambda$ inger et al., 1993; Bassell et al., 1994). Microtubules are particularly important for RNA transport in glia and neurons. In cultured oligodendrocytes, injected RNA during transport is physically adjacent to microtubules (Ainger et al., 1993). In cultured cortical neurons, the majority of in situ hybridization signal from endogenous poly $\mathrm{A}^{+}$RNA was within 50 $\mathrm{nm}$ of a microtubule, and most dendritic localization was lost 
after disruption of microtubules with colchicine (Bassell et al., 1994). While the dendritic transport mechanism is microtubule based, part of the selectivity for transport may be exclusionary in nature. Recent experiments by Kleiman, Banker, and Steward (1993) show that RNAs that usually remain in the cell body appear in dendrites when protein synthesis is blocked, suggesting that a rapidly turning-over protein may prevent dendritic transport of nondendritic RNAs.

Recent evidence suggests that microtubules and their associated MAPs may play a second, "exclusionary" role that excludes high molecular weight RNAs from axons. After $1 \mathrm{~d}$ in culture, cortical neurons transport poly $\mathrm{A}^{+}$RNAs into both dendrites and axons (Bassell et al., 1994). In the axon-like process, polyA ${ }^{+}$RNA extended throughout the majority of the process. However, after $4 \mathrm{~d}$ in culture, RNA was restricted to the most proximal axon segment. Likewise, in cultured hippocampal neurons, newly synthesized RNA was initially transported into both dendritic and axonal processes, but after 7-10 $\mathrm{d}$ in culture, it was excluded from axons (Kleiman et al., 1994). Exclusion of RNA from axons coincides with the maturation of the microtubule-based cytoskeleton, particularly the appearance of tightly bundled, microtubules characteristic of mature axons. Bassell et al. (1994) showed that poly ${ }^{+}$RNA was not observed in the vicinity of tightly hundled parallel microtubules, but was preferentially localized near loosely parallel or nonparallel microtubules. Earlier data showed that ribosomes, which were normally excluded from the axons of cultured chick sensory neurons, moved into axons after microtubules were disassembled by nocodazole, griseofulvin, or cold treatment (Baas et al., 1987), supporting the contention that microtubules prevent high molecular weight RNAs from entering axons.

How might these observations impinge on our data showing that OMP mRNA exists in the axons of olfactory receptor neurons? Perhaps because olfactory neurons are generated even in adult animals, their cytoskeleton lacks many components of mature neurons and retains cytoskeletal proteins usually found in immature neurons. For example, receptor neurons do not make neurofilaments (Vollrath et al., 1985) or MAP2, found in mature dendrites, while they continue to express MAP5 and vimentin, which usually disappear during maturation (Schwob et al., 1986; Viereck et al., 1989). Importantly, olfactory receptor axons do not have tau, an axon-specific MAP (Viereck et al., 1989), which has been shown to be responsible for bundling of microtubules in vitro (Hirokawa et al., 1988) and in vivo (Kanai et al., 1989; Lewis et al., 1989). Hence, it is likely that olfactory receptor axons lack tightly bundled microtubules that exclude mRNAs in most neurons. Electron micrographs from the frog and salamander olfactory nerve support this contention and show that the number of microtubules per axon is 2-5 (Burton, 1984; Burton and Wentz, 1992), too few to allow tight bundling. Therefore, our observations are fully consistent with the hypothesis that compartmentalization of translationally active cytoplasm away from translationally inactive axons is due to the exclusion of mRNA by tightly bundled microtubules organized by tau. Hence, the immature nature of the axonal cytoskeleton in olfactory neurons may resemble that observed in young cultures of primary neurons where polyA ${ }^{+}$and newly synthesized RNAs are transported into axons.

\section{References}

Ainger K, Avossa D, Morgan F, Hill SJ, Barry C, Barbarese E, Carson JH (1993) Transport and localization of exogenous myelin basic pro- tein mRNA microinjected into oligodendrocytes. J Cell Biol 123: 431-441.

Autilio LA, Appel SH, Pettis P, Gambetti P (1968) Biochemical studies of synapses in vitro I. Protein synthesis. Biochemistry 7:2615-2622.

Baas PW, Sinclair GI, Heidemann SR (1987) Role of microtubules in the cytoplasmic compartmentation of neurons. Brain Res 420:73-81.

Baker H, Grillo M, Margolis FL (1989) Biochemical and immunocytochemical characterization of olfactory marker protein in the rodent central nervous system. J Comp Neurol 285:246-261.

Barber PC, Lindsay RM (1982) Schwann cells of the olfactory nerves contain glial fibrillary acidic protein and resemble astrocytes. Neuroscience 7:3077-3090.

Bassell GJ, Singer RH, Kosik KS (1994) Association of poly(A) mRNA with microtubules in cultured neurons. Neuron 12:571-582.

Bruckenstein DA, Lein PJ, Higgins D, Fremeau RT Jr (1990) Distinct spatial localization of specific mRNAs in cultured sympathetic neurons. Neuron 5:809-819.

Buiakova OI, Rama Krishna NS, Getchell TV, Margolis FL (1994) Human and rodent OMP genes: conservation of structural and regulatory motifs and cellular localization. Genomics 20:452-462.

Burd GD (1993) Morphological study of the effects of intranasal zinc sulfate irrigation on the mouse olfactory epithelium and olfactory bulb. Microsc Res Tech 24:195-213.

Burgin KE, Waxham MN, Rickling S, Westgate SA, Mobley WC, Kelly PT (1990) In situ hybridization histochemistry of $\mathrm{Ca}^{2+} /$ calmodulindependent protein kinase in developing rat brain. J Neurosci 10: $1788-1798$.

Burton PR (1984) Luminal material in microtubules of frog olfactory axons: structure and distribution. I Cell Biol 99:520-528.

Burton PR, Wentz MA (1992) Neurofilaments are prominent in bullfrog olfactory axons but are rarely seen in those of the tiger salamander, Ambystoma tigrinum. J Comp Neurol 317:396-406.

Crews L, Hunter D (1994) Neurogenesis in the olfactory epithelium. Pers Dev Neurobiol 2:151-161.

Crispino M, Castigli E, Perrone Capano E, Martin R, Menichini E, Kaplan BB, Giuditta A (1993) Protein synthesis in a synaptosomal fraction from squid brain. Mol Cell Neurosci 4:366-374.

Denis-Donini S, Chini B, Vitadello M (1993) Developmentally regulated expression of CGRP in the mouse olfactory pathway. Eur $\mathbf{J}$ Neurosci 5:648-656.

Doucette R (1993) Glial cells in the nerve fiber layer of the main olfactory bulb of embryonic and adult mammals. Microsc Res Tech 24:113-130.

Ehrlich ME, Grillo M, Joh TH, Margolis FL, Baker H (1990) Transneuronal regulation of neuronal specific gene expression in the mouse olfactory bulb. Mol Brain Res 7:115-122.

Farbman AI, Margolis FL (1980) Olfactory marker protein during ontogeny: immunohistochemical localization. Dev Biol 74:205-215.

Fass B, Steward O (1983) Increases in protein-precursor incorporation in the denervated neuropil of the dentate gyrus during reinnervation. Neuroscience 9:653-664.

Fung BP, Brilliant MH, Chikaraishi DM (1991) Brain-specific polyAtranscripts are detected in polyA ${ }^{+}$RNA: do complex polyA- brain RNAs really exist? I Neurosci 11:701-708.

Gainer H, Tasaki I, Lasek R (1977) Evidence for the glia-neuron protein transfer hypothesis from intracellular perfusion studies of squid giant axons. J Ccll Biol 74:524-530.

Garner CC, Tucker RP, Matus A (1988) Selective localization of messenger RNA for cytoskeletal protein MAP2 in dendrites. Nature 336: 674-677.

Giuditta A, Menichini E, Perrone Capano E, Langella M, Martin R, Castigli E, Kaplan BB (1991) Active polysomes in the axoplasm of the squid giant axon. J Neurosci 28:18-28.

Grillo M, Margolis FL (1990) Use of reverse transcriptase polymerase chain reaction to monitor expression of intronless genes. Biotechniques 9:262-268.

Hirokawa N, Shiomura Y, Okabe S (1988) Tau proteins: the molecular structure and mode of binding on microtubules. J Cell Biol 107: 1449-1461.

Jirikowski GF, Sanna PP, Bloom FE (1990) mRNA coding for oxytocin is present in axons of the hypothalano-neurohypophysial tract. Proc Natl Acad Sci USA 87:7400-7404.

Jirikowski GF, Sanna PP, Maciejewski-Lenoir D, Bloom FE (1992) Reversal of diabetes insipidus in Brattleboro rats: intrahypothalamic injection of vasopressin mRNA. Science 255:996-998. 
Jones DT, Reed RR (1989) $\mathrm{G}_{\mathrm{olf}}$ : an olfactory neuron specific-G protein involved in odorant signal transduction. Science 244:790-795.

Kanai Y, Takemura R, Oshima T, Mori H, Ihara Y, Yanagisawa M, Masaki T, Hirokawa N (1989) Expression of multiple tau isoforms and microtubule bundle formation in fibroblasts transfected with a single tau cDNA. J Cell Biol 109:1173-1184.

Kawano T, Margolis FL (1982) Transynaptic regulation of olfactory bulb catecholamines in mice and rats. J Neurochem 39:342-348.

Kleiman R, Banker G, Steward O (1990) Differential subcellular localization of particular mRN $\Lambda \mathrm{s}$ in hippocampal neurons in culture. Neuron 5:821-830.

Kleiman R, Banker G, Steward O (1993) Inhibition of protein synthesis alters the subcellular distribution of mRNA in neurons but does not prevent dendritic transport of RNA. Proc Natl Acad Sci USA 90: 11192-11196.

Kleiman R, Banker G, Steward O (1994) Development of subcellular mRNA compartmentation in hippocampal neurons in culture. J Neurosci 14:1130-1139.

Koenig E (1991) Evaluation of local synthesis of axonal proteins in the goldfish Mauthner cell axon and axons of dorsal and ventral roots of the rat in vitro. Mol Cell Neurosci 2:384-394.

Lewis SA, Ivanov IE, Lee G-H, Cowan NJ (1989) Organization of microtubules in dendrites and axons is determined by a short hydrophobic zipper in microtubule-associated proteins $\mathrm{M} \Lambda \mathrm{P} 2$ and tau. $\mathrm{Na}$ ture 342:-505.

Litman P, Barg J, Rindzoonski L, Ginzburg I (1993) Subcellular localization of Tau mRNA in differentiating neuronal cell culture: implications for neuronal polarity. Neuron 10:627-638.

Maciejewski-Lenoir D, Jirikowski GF, Sanna PP, Bloom FE (1993) Reduction of exogenous vasopressin RNA poly(A) tail length increases its effectiveness in transiently correcting diabetes insipidus in the Brattleboro rat. Proc Natl Acad Sci USA 90:1435-1439.

Margolis FL (1980) A marker protein for the olfactory chemoreceptor neuron. In: Proteins of the nervous system (Bradshaw RA, Schneider D, eds), pp 59-84. New York: Raven.

McCabe JT, Lehman E, Chastrette N, Hanze J, Lang RE, Ganten D, Pfaff DW (1990) Detection of vasopressin mRNA in the neurointermediate lobe of the rat pituitary. Mol Brain Res 8:325-329.

Melton DA, Kreig PA, Rebagliati MR, Maniatis T, Zinn K, Green MR (1984) Efficient in vitro synthesis of biologically active RNA and RNA hybridization probes from plasmids containing a bacteriophage S.26 promoter. Nucleic Acids Res 12:7035-7056.

Menichini E, Castigli E, Kaplan BB, Giuditta A (1990) Synthesis of axoplasmic RNA particles in the isolated squid giant axon. Neurosci Res Commun 7:89-96.

Mohr E, Zhou A, Thorn NA, Richter D (1990) Rats with physically disconnected hypothalmo pituitary tracts no longer contain vasopressin-oxytocin gene transcripts in the posterior pituitary lobe. FEBS Lett 263:332-336.

Mohr E, Fehr S, Richter D (1991) Axonal transport of neuropeptide encoding mRNAs within the hypothalamo-hypophysial tract of rats. EMBO J 10:2419-2424.

Monti-Graziadei GA, Stanley RS, Graziadei PPC (1980) The olfactory marker protein in the olfactory system of mouse during development. Neuroscience 5:1239-1252.

Murphy D, Levy A, Lightman S, Carter D (1989) Vasopressin RNA in the neural lobe of the pituitary: dramatic accumulation in response to salt loading. Proc Natl Acad Sci USA 86:9002-9005.

Nadi NS, Head R, Grillo M, Hempstead J, Granot-Reisfeld N, Margolis FL (1981) Chemical deafferentiation of the olfactory bulb: plasticity of the levels of tyrosine hydroxylase, dopamine and norepinephrine. Brain Res 213:365-377.

Pixley SK (1992) The olfactory nerve contains two populations of glia, identified both in vivo and in vitro. Glia 5:269-284.

Rao A, Steward O (1991) Evidence that protein constituents of postsynaptic membrane specializations are locally synthesized: analysis of proteins synthesized within synaptosomes. J Neurosci 11:28812895.

Ressler KJ, Sullivan SL, Buck LB (1994) Information coding in the olfactory system: evidence for a stereotyped and highly organized epitope map in the olfactory bulb. Cell 79:1245-1255.

Rogers KE, Grillo M, Sydor W, Poonian M, Margolis FL (1985) Olfactory neuron-specific protein is translated from a large poly $(\mathrm{A})^{+}$ mRNA. Proc Natl Acad Sci USA 82:5218-5222.

Rogers KE, Dasgupta P, Gubler U, Grillo M, Khew-Goodall YS, Margolis FL (1987) Molecular cloning and sequencing of a cDNA for olfactory marker protein. Proc Natl Acad Sci USA 84:1704-1708.

Schwob JE, Farber NB, Gottlieb DI (1986) Neurons of the olfactory cpithelium in adult rats contain vimentin. $\mathrm{J}$ Ncurosei 6:208-217.

Simmons DM, Arriza JL, Swanson LW (1989) A complete protocol for in situ hybridization messenger RNAs in brain and other tissues with radiolabeled single stranded RNA probe. J Histotechnol 12:169181 .

Singer RH (1993) RNA zipcodes for cytoplasmic addresses. Curr Biol 3:719-721.

Singer RH, Langevin GL, Lawrence JB (1989) Ultrastructural visualization of cytoskeletal mRNAs and their associated proteins using double-label in situ hybridization. J Cell Biol 108:2343-2353.

Skutella T, Probst JC, Blanco E, Jirikowski GF (1994) Localization of tyrosine hydroxylase mRNA in the axons of the hypothalamo-neurohypophysial system. Mol Brain Res 23:179-184.

Steward O (1983) Alterations in polyribosomes associated with dendritic spines during the reinnervation of the dentate gyrus of the adult rat. J Neurosci 3:177-188.

Steward O, Banker GA (1992) Getting the message from the gene to the synapse: sorting and intracellular transport of RNA in neurons. Trends Neurosci 15:180-186.

Steward O, Levy WB (1982) Preferential localization of polyribosomes under the base of dendritic spines in granule cells of the dentate gyrus. J Neurosci 2:284-291.

Stone DM, Grillo M, Margolis FL, Joh TH, Baker H (1991) Differential effect of functional olfactory bulb deafferentation on tyrosine hydroxylase and glutamic acid decarboxylase messenger RNA levels in rodent juxtaglomerular neurons. J Comp Neurol 311:223-233.

Tiedge H, Fremeau RT Jr, Weinstock PH, Arancio O, Brosius J (1991) Dendritic location of neural BC1 RNA. Proc Natl Acad Sci USA 88: 2093-2097.

Tiedge H, Zou A, Thorn NA, Brosius J (1993) Transport of BC1 RNA in hypothalamo-neurohypophysial axons. J Neurosci 13:4144-4219.

Torre ER, Steward O (1992) Demonstration of local protein synthesis within dendrites using a new cell culture system that permits the isolation of living axons and dendrites from their cell bodies. J Neurosci 12:762-772.

Trembleau A, Morales M, Bloom FE (1994) Aggregation of vasopressin mRNA in a subset of axonal swellings of the median eminence and posterior pituitary: light and electron microscopic evidence. J Neurosci 14:39-53.

Tucker RP, Garner CC, Matus A (1989) In situ localization of microtubule-associated protein mRNA in the developing and adult rat brain. Neuron 2:1245-1256

Van Minnen J (1994) RNA in the axonal domain: a new dimension in neuronal functioning. Histochem $\mathbf{J}$, in press.

Vassar R, Chao SK, Sitcheran R, Nunez JK, Vosshall LB, Axel R (1994) Topological organization of sensory projections to the olfactory bulb. Cell 79:981-991.

Verity MA, Brown WJ, Cheung M (1980) Isolation of ribosome containing synaptosome subpopulations with active in vitro protein synthesis. J Neurosci Res 5:143-153.

Viereck C, Tucker RP, Matus A (1989) The adult rat olfactory system expresses microtubule-associaled proteins found in the developing brain. J Neurosci 9:3547-3557.

Vollrath M, Altmannsberger M, Weber K, Osborn M (1985) An ultrastructural and immunohistological study of the rat olfactory epithelium: unique properties of olfactory sensory cells. Differentiation 29: 243-253.

Yisraeli JK, Sokol S, Melton DA (1990) A two-step model for the localization of maternal mRNA in Xenopus oocytes: involvement of microtubules and microfilaments in the translocation and anchoring of $\mathrm{Vg} 1$ mRNA. Development 108:289-298. 